\title{
Isolated CNS Relapse in Acute Lymphoblastic Leukemia (ALL): An Experience from a Tertiary Care Center
}

\author{
Sanjeevan Sharma ${ }^{4}$ \\ ${ }^{1}$ Department of Pathology, Command Hospital, Pune, \\ Maharashtra, India \\ ${ }^{2}$ Department of Pathology, Armed Forces Medical College, Pune, \\ Maharashtra, India \\ ${ }^{3}$ Department of Lab Sciences and Mol Medicine, Army Hospital \\ (R\&R), Delhi, India \\ ${ }^{4}$ Department of Medicine and of Haematology, Command Hospital, \\ Lucknow, Uttar Pradesh, India
}

Manvir Singh Tevatia ${ }^{1}$ Isha Sharma ${ }^{2}$ Toyaja Jadhav ${ }^{2}$ Venkatesan Somasundaram ${ }^{3 .}$

\begin{abstract}
Address for correspondence Venkatesan Somasundaram, MD, DM, Department of Lab Sciences and Mol Medicine, Army Hospital (R\&R), Delhi 110010, India (e-mail: Itcolsvenkatesan@gmail.com).
\end{abstract}

J Lab Physicians 2021;13:134-138.

\begin{abstract}
Aims and Objectives In this study the various parameters of acute lymphoblastic leukemia (ALL), including the clinical features, peripheral blood and bone marrow (BM) findings, immunophenotypic and cytogenetic details in ALL cases who had isolated relapse involving the central nervous system (CNS), were studied.

Patients/Materials and Methods Duration of the study is from 2015 to 2019 in which $5 \mathrm{ALL}$ cases were presented to this tertiary care center. The presenting symptoms varied from headache, fever, and distension of abdomen. These cases were either on therapy or post completion of chemotherapy. The diagnosis of CNS relapse followed after the examination of cerebrospinal fluid (CSF). Patients also underwent BM examination to rule out systemic relapse.

Results Age of patients ranged from 7 months to 42 years. There were three female patients. Two patients had isolated CNS relapse 3.5 years after completing therapy and succumbed to their illness. Two patients had $t(9 ; 22)$ while one patient had $t(1 ; 14)$ cytogenetic abnormality at diagnosis. One patient was diagnosed as T-ALL. Treatment offered was German Multicentre ALL protocol for induction along with 10 cycles of maintenance.

\section{Keywords}

- acute lymphoblastic leukemia (ALL)

- cerebrospinal fluid

- bone marrow

- central nervous system

Conclusion The most common hematolymphoid malignancy in children namely ALL accounts for $75 \%$ of childhood leukemias. Complete remission rates reach up to 70 to $80 \%$. CNS involvement is known to occur in these cases. CNS relapse may occur alone or with systemic relapse. Advances in therapeutic protocols along with CNS prophylaxis have drastically brought down the rates of CNS relapse. It is essential to maintain a high degree of suspicion so that these cases of isolated CNS relapse can be identified at the earliest and definitive therapy can be offered.
\end{abstract}

published online June 15, 2021
DOI https://doi.org/

$10.1055 / \mathrm{s}-0041-1730752$ ISSN $0974-2727$ (c) 2021. The Indian Association of Laboratory Physicians.

This is an open access article published by Thieme under the terms of the Creative Commons Attribution-NonDerivative-NonCommercial-License, permitting copying and reproduction so long as the original work is given appropriate credit. Contents may not be used for commercial purposes, or adapted, remixed, transformed or built upon. (https://creativecommons.org/licenses/by-nc-nd/4.0/).

Thieme Medical and Scientific Publishers Pvt. Ltd. A-12, 2nd Floor, Sector 2, Noida-201301 UP, India 


\section{Introduction}

Precursor lymphoid neoplasm is composed of precursor lymphoid cells/lymphoblasts involving bone marrow (BM) and/or peripheral blood (PB). When the disease is limited to $\mathrm{BM}$ and $\mathrm{PB}$, it is called acute lymphoblastic leukemia (ALL). Sometimes the disease presents primarily as lymph node or extranodal disease and is called as lymphoblastic lymphoma (LBL). ${ }^{1}$ Immunophenotypically ALL/LBL can be of T-cell or B-cell phenotype.

ALL is a disease of children and in less than 6-year age group contributes to $75 \%$ of all cases. The annual incidence ranges from 1 to 4.75 cases per one lakh population worldwide. $^{2}$ One of the literature review point out that approximately two-thirds of 98 reported cases were less than 18 years of age. ${ }^{3}$

Nearly $85 \%$ of ALL/LBL is of B-cell phenotype while remaining $15 \%$ of childhood ALL cases belong to T-cell phenotype. The sites such as liver, spleen, tonsils, central nervous system (CNS), testes, and skin may be involved in T-ALL while $\mathrm{BM}$ is always involved in B/T-ALL. In addition, mediastinal involvement is often seen in T-ALL/LBL. ${ }^{4}$ At the time of diagnosis, around $6 \%$ of ALL patients show CNS involvement, ${ }^{5}$ and if no CNS prophylaxis is given, then CNS disease is likely in 50 to $75 \%$ of patients. On the contrary, when CNS prophylaxis is instituted, CNS disease is likely in 2 to $10 \%$ of ALL patients, thus improving the long-term prognosis. ${ }^{6}$

Complete remission (CR) following induction therapy in ALL is defined as BM with $<5 \%$ leukemic blast cells, no blasts in $\mathrm{PB}$, absence of organomegaly and lymphadenopathy, and normalization of PB counts. Systemic relapse is reappearance of disease in the form of more than $0.05 \%$ blasts in PB or BM after achieving CR. Isolated CNS relapse is characterized by infiltration of blasts in cerebrospinal fluid (CSF) or developing clinical signs pointing toward CNS leukemia which include focal neurological deficit or hypothalamic syndrome, eye involvement in case of ALL after achieving CR and in the absence of medullary relapse. This study compiles the clinical features of a series of ALL cases that showed isolated CNS relapse and elaborates on their outcome to therapy. As far as our knowledge goes, this is one of very few studies conducted on this subject in Indian subcontinent which will help in improving the existing therapeutic modalities and introduction of newer targeted drugs against patients of ALL with CNS involvement.

\section{Materials and Methods}

Retrospective study was carried in a tertiary care center over a period of 4 years (2015-2019). All admitted patients with ALL who had isolated CNS relapse of both sexes and all ages formed part of this study. Data including age, clinical presentations, biochemical parameters and treatment, and relapse were analyzed. PBS, BM examination, CSF study, flow cytometry for immunophenotyping, karyotyping, and mutational analysis were done for all patients. Wright's stain was used for staining PB and BM smears. Marrow tissue was processed using Leica ASP 300S automated tissue processing system and stained with hematoxylin \& eosin and reticulin stains. Bone marrow biopsies were also subjected to immunohistochemistry.

\section{Result}

Five patients of ALL who had isolated CNS relapse were subjected to further analysis and following results were drawn:

Age and sex: Age at diagnosis ranged from 7 months to 44 years. Four out of five patients belonged to the less-than-6-years age group. Three out the five patients were females.

Presenting complaint: The presenting complaints were varied and atypical ranging from fever, lethargy, headache, dysphagia, and breathing difficulties to neck swelling, and abdominal distension.

Presenting white blood cell (WBC) count (total leukocyte count) at diagnosis: Total leukocyte count in these cases ranged from $2,600 / \mathrm{m}^{3}$ to $1,20,200 / \mathrm{m}^{3}$.

Blast percentage: PBS showed heterogenous population of blasts ranging from 2 to $85 \%$. BM examination was performed which confirmed the diagnosis of acute leukemia. Myeloperoxidase (MPO) stain was performed, and all the cases were MPO negative. The initial CSF done was negative for blasts in all the cases. Subsequent to induction chemotherapy, BM aspirate showed marrow in remission in four out of five patients while the fifth patient did not attend OPD for follow-up and later presented with relapse. The minimal residual disease panel was run at various time points and was negative in all cases before the patients presented with isolated CNS relapse.

Immunophenotyping: The flow cytometry for immunophenotyping showed that one out of five patients had a T-cell phenotype with positivity for $\mathrm{CD} 2, \mathrm{cCD} 3, \mathrm{CD} 5, \mathrm{CD} 7$, and TdT; the rest are of B-cell immunophenotype with positivity for CD19, CD22, and Cd79a out of which one of them had a Pre B-cell Phenotype.

Remission and post remission CSF: The duration of remission ranged from 13 months to 36 months following which a CSF examination was performed which was negative for blasts in all patients.

Presenting complaints in relapse: Post remission the patients presented with an array of symptoms ranging from fever in three out of five patients and global headache and vomiting in the rest two patients.

CSF examination post relapse: CSF examination was positive for blasts in all of the patients with relapse with WBC count ranging from $180 / \mathrm{m}^{3}$ to $1,800 / \mathrm{m}^{3}$ (-Figs. 1 and 2 ). Cell block was prepared from the CSF in a case of T-ALL which showed blasts with high nucleocytoplasmic ratio and was subjected to immunohistochemistry with positivity for CD3 and TdT confirming the CNS involvement by T-lymphoblastic leukemia (-Fig. 3).

Noncontrast computed tomography (NCCT) head in the same case showed confluent hypodense areas in bilateral centrum semiovales and white matter of bilateral frontoparietal lobes suggestive of chronic nonspecific ischemic changes (-Fig. 4). 


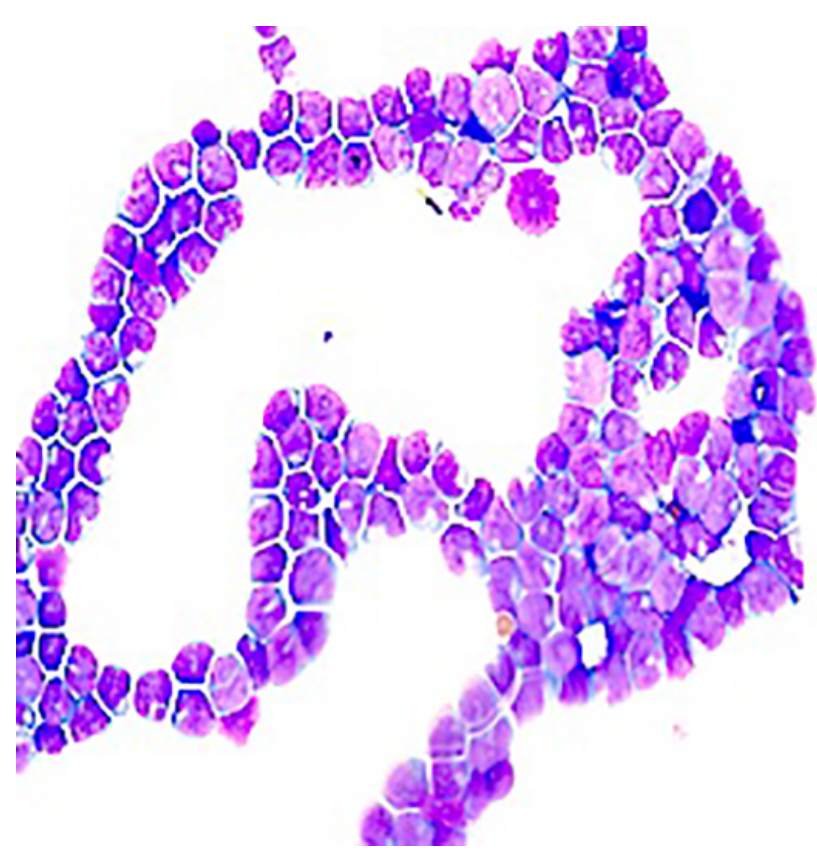

Fig. 1 CSF smear showing blasts in cases of ALL (400x). ALL, acute lymphoblastic leukemia; CSF, cerebrospinal fluid.

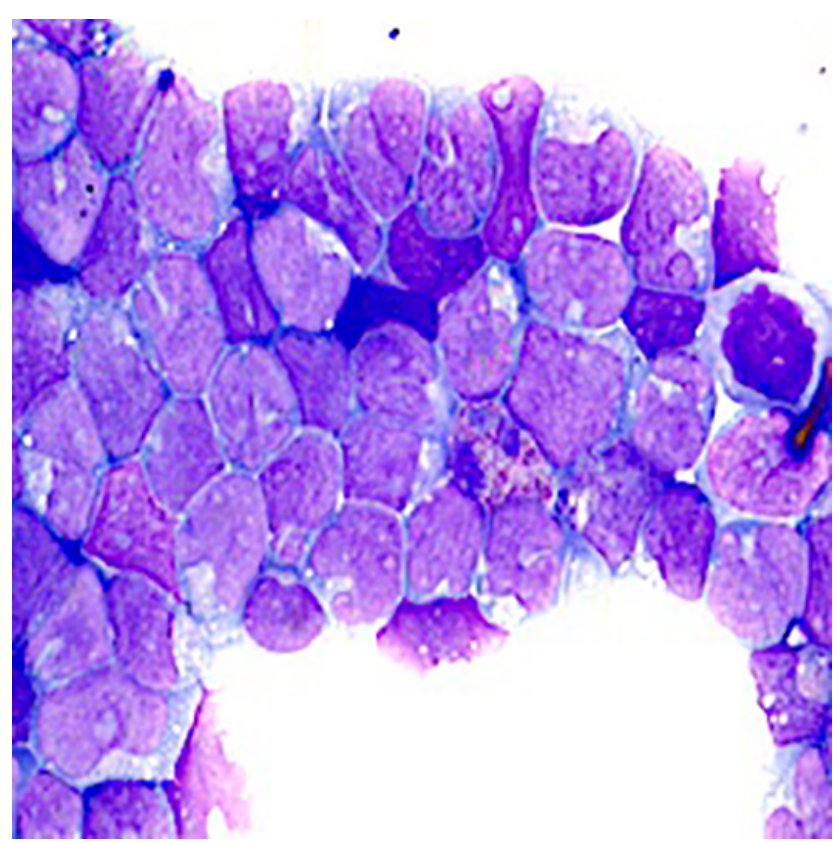

Fig. 2 Blasts showing high $\mathrm{N} / \mathrm{C}$ ratio, folded nuclei, and prominent nucleoli in CSF (1000×). CSF, cerebrospinal fluid.

Bone marrow aspirate: BM aspirate showed marrow in remission in all of these cases.

Karyotype: Two of the patients showed a $t(9,22)$ with one of them showing an extra Philadelphia chromosome. One of the patients showed a chromosome 22 gain with s chromosome 14 loss, while the other three patients had a normal karyotype.

Mutational analysis: Two out of five patients showed a BCR-ABL gene rearrangement. In one patient, MLL gene rearrangement was identified on fluorescent in situ hybridization.

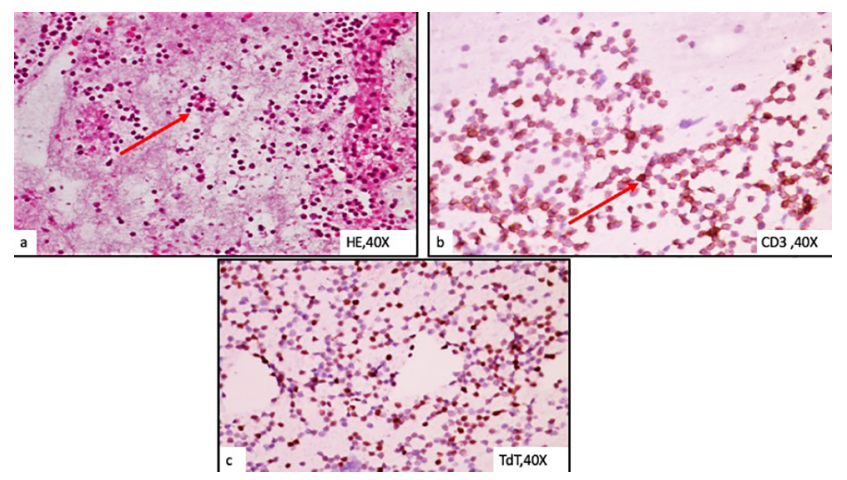

Fig. 3 (A) Cell block prepared from a case of T-ALL showing blasts with high nucleocytoplasmic ratio and scant cytoplasm (H\&E stain, 400x). (B) Immunohistochemistry of the cell block showing blasts, positive for CD3 (IHC for CD3, 400×). (C) Immunohistochemistry of the cell block showing blasts positive for Tdt (IHC for Tdt, 400×). ALL, acute lymphoblastic leukemia; IHC, immunohistochemistry.

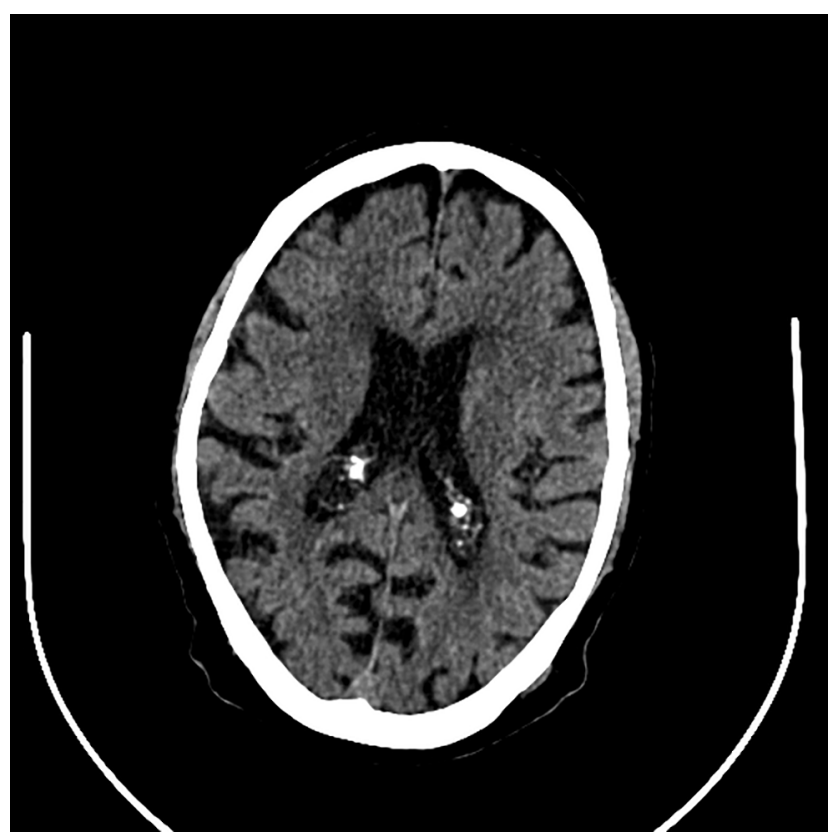

Fig. 4 NCCT head showing nonspecific ischemic white matter changes. NCCT, noncontrast computed tomography.

Treatment administered: All the patients were given routine induction followed by maintenance CT. Patients who presented post remission with isolated CNS relapse were also given triple intrathecal regimen and cranial irradiation according to age and weight.

Outcome: Three out of five patients showed improvement and are under follow-up, while two patients succumbed to their illness.

\section{Discussion}

CNS disease is known in hematological malignancies such as ALL and in aggressive non-Hodgkin's lymphoma (NHL). Most of them respond to treatment while refractory disease is highest with primary CNS and ocular lymphoma in up 
to $90 \%$ of the cases. ${ }^{7,8}$ Among ALL cases, the risk is higher in adults as compared with children as also in cases of Burkitt's lymphoma and these patients have $50 \%$ risk of developing CNS disease. ${ }^{9,10}$ The risk of CNS relapse is lowest in diffuse

Table 1 Classification of CNS disease in CSF in cases of ALL patients ${ }^{15}$

\begin{tabular}{|l|l|}
\hline CNS-1 & Absence of identifiable leukemic cells in CSF \\
\hline CNS-2 & $\begin{array}{l}\text { Presence of blast cells in a sample that } \\
\text { contains }<5 \mathrm{WBC} / \mu \mathrm{L}\end{array}$ \\
\hline CNS-3 & $\begin{array}{l}\text { Sample that contains } \geq 5 \mathrm{WBC} / \mu \mathrm{L} \text { with } \\
\text { identifiable blast cells, or the presence of } \\
\text { a cerebral mass or cranial nerve palsy with } \\
\text { leukemic cells in CSF }\end{array}$ \\
\hline
\end{tabular}

Abbreviations: CNS, central nervous system; CSF, cerebrospinal fluid; ALL, acute lymphoblastic leukemia. large B-cell lymphoma (approximately 5\% ) and indolent NHL $(<5 \%) \cdot{ }^{11-13}$

The most common hematolymphoid malignancy in children is ALL, which contributes one-fourth of all malignancies in childhood and $75 \%$ of all leukemias. The CR rates reach up to 70 to $80 \%{ }^{14}$ Isolated CNS relapse in ALL patients is rare as limited data are available from India on literature search. Hence an attempt was made to compile and present the data of ALL cases with isolated CNS relapse and compare the clinicopathological profile of these cases with the final outcome.

The following findings in our study are consistent with current literature. Majority of the patients belong to age group less than 6 years. Majority presented with raised WBC count which is an independent poor prognostic marker. Increased CSF WBC count with positivity for blasts is associated with poor outcome and can be graded as per - Table $\mathbf{1 . 1 5 , 1 6}$ In our study all patient belonged to CNS-3 disease having poor prognosis.

Table 2 Clinicopathological analysis and comparison of all patients

\begin{tabular}{|c|c|c|c|c|c|}
\hline & Case 1 & Case 2 & Case 3 & Case 4 & Case 5 \\
\hline Age/sex & $04 \mathrm{y} /$ Female & $44 \mathrm{y} /$ Male & 07 mo/Female & $05 \mathrm{y} /$ Female & $04 \mathrm{y} /$ Male \\
\hline Presentation & $\begin{array}{l}\text { May } 2017 \\
\left(\mathrm{TLC}=1,20,000 / \mathrm{m}^{3}\right)\end{array}$ & $\begin{array}{l}\text { Feb } 2015 \\
\left(\mathrm{TLC}=4,900 / \mathrm{m}^{3}\right)\end{array}$ & $\begin{array}{l}\text { Aug } 2015 \\
\left(\mathrm{TLC}=38,700 / \mathrm{m}^{3}\right)\end{array}$ & $\begin{array}{l}\text { May } 2015 \\
\left(\mathrm{TLC}=2,600 / \mathrm{m}^{3}\right)\end{array}$ & $\begin{array}{l}\text { July } 2013 \\
\left(\mathrm{TLC}=1,10,000 / \mathrm{m}^{3}\right)\end{array}$ \\
\hline IPT/cytogenetics & $\begin{array}{l}\text { B cell } \\
\mathrm{t}(9 ; 22) \\
\text { Extra Ph chr + }\end{array}$ & $\begin{array}{l}\text { T cell } \\
\mathrm{t}(1 ; 14)\end{array}$ & $\begin{array}{l}\text { B cell } \\
\text { MLL gene rear- } \\
\text { rangement + }\end{array}$ & B cell & $\begin{array}{l}\text { B cell } \\
t(9 ; 22) \\
\text { Loss of chr } 14 \\
\text { Gain of chr } 22\end{array}$ \\
\hline Initial CSF & Negative for blasts & $\begin{array}{l}\text { Negative for } \\
\text { blasts }\end{array}$ & Negative for blasts & $\begin{array}{l}\text { Negative for } \\
\text { blasts }\end{array}$ & Negative for blasts \\
\hline Remission & $\begin{array}{l}\text { Lost to follow-up. } \\
\text { Presented with } \\
\text { relapse. } \\
\text { Remission on } \\
\text { February 23, } 2018 . \\
\text { BM aspirate and } \\
\text { biopsy: } \\
\text { bone marrow in } \\
\text { remission. }\end{array}$ & $\begin{array}{l}\text { October 15, } 2015 \\
\text { BM aspirate and } \\
\text { biopsy: } \\
\text { bone marrow in } \\
\text { remission. }\end{array}$ & $\begin{array}{l}\text { October } 30,2015 \\
\text { BM aspirate and } \\
\text { biopsy: } \\
\text { bone marrow in } \\
\text { remission. }\end{array}$ & $\begin{array}{l}\text { March 31, } 2016 \\
\text { BM aspirate and } \\
\text { biopsy: } \\
\text { bone marrow in } \\
\text { remission. }\end{array}$ & $\begin{array}{l}\text { September 23, } 2014 \\
\text { BM aspirate and biopsy: } \\
\text { bone marrow in remission }\end{array}$ \\
\hline MRD status & $\begin{array}{l}\text { February 23, } 2018 \\
\text { MRD negative }\end{array}$ & $\begin{array}{l}\text { October 15, } 2015 \\
\text { MRD negative }\end{array}$ & $\begin{array}{l}\text { October 30, } 2015 \\
\text { MRD negative }\end{array}$ & $\begin{array}{l}\text { September 09, } 15 \\
\text { MRD negative. }\end{array}$ & $\begin{array}{l}\text { September 23, } 2014 \\
\text { MRD negative }\end{array}$ \\
\hline $\begin{array}{l}\text { Post remission } \\
\text { CSF }\end{array}$ & Negative for blasts & $\begin{array}{l}\text { Negative for } \\
\text { blasts }\end{array}$ & Negative for blasts & $\begin{array}{l}\text { Negative for } \\
\text { blasts }\end{array}$ & Negative for blasts \\
\hline $\begin{array}{l}\text { Duration of } \\
\text { remission }\end{array}$ & $13 \mathrm{mo}$ & $36 \mathrm{mo}$ & $18 \mathrm{mo}$ & $35 \mathrm{mo}$ & $34 \mathrm{mo}$ \\
\hline $\begin{array}{l}\text { Presenting } \\
\text { symptoms }\end{array}$ & Fever, headache & $\begin{array}{l}\text { High-grade } \\
\text { fever, severe } \\
\text { global headache, } \\
\text { vomiting. }\end{array}$ & $\begin{array}{l}\text { High-grade fever } \\
\text { with chills }\end{array}$ & $\begin{array}{l}\text { Early morning } \\
\text { headache. }\end{array}$ & Fever, headache \\
\hline $\begin{array}{l}\text { CSF showed } \\
\text { blasts (relapse) }\end{array}$ & $\begin{array}{l}\text { March } 19,2019 \\
\text { WBC: } 848 / \mathrm{m}^{3} \\
\text { RBC: } 193 / \mathrm{m}^{3}\end{array}$ & $\begin{array}{l}\text { November } 10 \text {, } \\
2018 \\
\text { WBC: } 180 / \mathrm{m}^{3} \\
\text { RBC: } 7,100 / \mathrm{m}^{3}\end{array}$ & $\begin{array}{l}\text { March } 26,2017 \\
\text { WBC: } 350 / \mathrm{m}^{3} \\
\text { RBC: } 01 / \mathrm{m}^{3}\end{array}$ & $\begin{array}{l}\text { August 08, } 2018 \\
\text { WBC: } 220 / \mathrm{m}^{3} \\
\text { RBC: } 04 / \mathrm{m}^{3} .\end{array}$ & $\begin{array}{l}\text { July } 05,2016 \\
\text { WBC: } 1,800 / \mathrm{m}^{3} \\
\text { RBC: } 10 / \mathrm{m}^{3}\end{array}$ \\
\hline $\begin{array}{l}\text { Bone marrow } \\
\text { examination }\end{array}$ & $\begin{array}{l}\text { Bone marrow in } \\
\text { remission }\end{array}$ & $\begin{array}{l}\text { Bone marrow in } \\
\text { remission }\end{array}$ & $\begin{array}{l}\text { Bone marrow in } \\
\text { remission }\end{array}$ & $\begin{array}{l}\text { Bone marrow in } \\
\text { remission }\end{array}$ & Bone marrow in remission \\
\hline Radiotherapy & $18 \mathrm{~Gy} \times 11 \mathrm{~d}$ & $18 \mathrm{~Gy} \times 11 \mathrm{~d}$ & $18 \mathrm{~Gy} \times 7 \mathrm{~d}$ & $18 \mathrm{~Gy} \times 11 \mathrm{~d}$ & 18 Gy x $11 \mathrm{~d}$ \\
\hline Present status & On follow-up & On follow-up & $\begin{array}{l}\text { Died (August 29, } \\
\text { 2017) }\end{array}$ & On follow-up & Died (December 12, 2016) \\
\hline
\end{tabular}

Abbreviations: CSF, cerebrospinal fluid; IPT, immunophenotyping; MLL, mixed-lineage leukemia; MRD, minimal residual disease; RBC, red blood cell; TLC, total leukocyte count. 
Other major factors such as T-cell immunophenotype and high disease burden were associated with an increased risk of relapse in the CNS. Patients with pre-B ALL with the $t(1 ; 19)$, CNS disease, T-ALL have higher risk of CNS relapse as brought by St. Jude Children Hospital trial, which is in concordance with our study in which one patient had a T-ALL phenotype, however, none of the cases had blasts in the initial CSF examination at the onset of therapy. ${ }^{17}$

Risk of CNS relapse is higher with cases showing additional high-risk cytogenetic and genetic abnormalities. Cytogenetic abnormalities with high risk CNS disease include $\mathrm{t}(9 ; 22), \mathrm{t}(1 ; 19), \mathrm{t}(4 ; 11)$, and hypodiploidy. ${ }^{18}$ In our study two of the patients showed at $t(9,22)$ with one of them showing an extra Philadelphia chromosome. In one patient, MLL gene rearrangement was identified on FISH.

More than half of the pediatric patients are likely to develop CNS relapse if they do not get CNS prophylaxis chemotherapy and similar is the case with adults. Hence CNS prophylaxis after induction chemotherapy with intrathecal methotrexate combined with craniospinal irradiation (approximately 2,400 cGy in 12 fractions over 2.5 weeks) for patients $>1$ year of age decreases CNS relapse from $30 \%$ to $<5 \%$ and prevents early CNS disease and is mandatory in ALL. ${ }^{19}$ The same treatment is being administered in our study showing favorable outcome on follow-up of patients.

\section{Conclusion}

CNS recurrence is known to result in very poor prognosis in cases of ALL, hence greater attention has to be devoted to this complication. CNS relapse can occur as an isolated phenomenon, along with systemic relapse or following systemic relapse. Unless there is change in the systemic therapy, most of the cases with isolated CNS relapse will die or will relapse at a later date. Adult patients also meet a similar fate.

Our study focuses on analyzing the clinicopathological profile of ALL patients with isolated CNS relapse which is a rare event and highlights the various poor prognostic markers associated with it (-Table 2). ALL with isolated CNS relapse has a myriad of clinical presentations and thus a high index of clinical suspicion is required to alert the clinicians especially the pediatricians as most patients are children and are followed up by pediatricians.

\section{Conflict of Interest}

None.

\section{References}

1 Borowitz MJ, Chan JKC, Downing JR, Lebeau MM, Arber DA, Blymphoblastic leukaemia/lymphoma, not otherwise specified (NOS). In: Swerdlow SH, Campo E, eds. WHO Classification of Tumours of Haematopoietic and Lymphoid Tissues. Cours Albert Thomas, Lyon: International Agency For Research on Cancer;2017:200- 202
2 Redaelli A, Laskin BL, Stephens JM, Botteman MF, Pashos CL. A systematic literature review of the clinical and epidemiological burden of acute lymphoblastic leukaemia (ALL) Eur J Cancer Care (Engl) 2005;14(1):53-62

3 Maitra A, McKenna RW, Weinberg AG, Schneider NR, Kroft SH. Precursor B-cell lymphoblastic lymphoma. A study of nine cases lacking blood and bone marrow involvement and review of the literature. Am J Clin Pathol 2001;115(6):868-875

4 Borowitz MJ, Chan JKC, Bene MC, Arber DA, T-lymphoblastic leukaemia/lymphoma. In: Swerdlow SH, Campo E, eds. WHO Classification of Tumours of Haematopoietic and Lymphoid Tissues. Cours Albert Thomas, Lyon: International Agency For Research on Cancer; 2017: 209-212

5 Dass J, Dayama A, Mishra PC, et al. Higher rate of central nervous system involvement by flow cytometry than morphology in acute lymphoblastic leukemia. Int J Lab Hematol 2017;39(5):546-551

6 Surapaneni UR, Cortes JE, Thomas D, et al. Central nervous system relapse in adults with acute lymphoblastic leukemia. Cancer 2002;94(3):773-779

7 Hormigo A, Abrey L, Heinemann MH, DeAngelis LM. Ocular presentation of primary central nervous system lymphoma: diagnosis and treatment. Br J Haematol 2004;126(2):202-208

8 Jahnke K, Thiel E, Martus P, et .German Primary Central Nervous System Lymphoma Study Group. Relapse of primary central nervous system lymphoma: clinical features, outcome and prognostic factors. J Neurooncol 2006;80(2):159-165

9 Simone JV. History of the treatment of childhood ALL: a paradigm for cancer cure. Best Pract Res Clin Haematol 2006;19(2):353-359

10 Cortes J, O'Brien SM, Pierce S, Keating MJ, Freireich EJ, Kantarjian HM. The value of high-dose systemic chemotherapy and intrathecal therapy for central nervous system prophylaxis in different risk groups of adult acute lymphoblastic leukemia. Blood 1995;86(6):2091-2097

11 Hoelzer D, Gökbuget N. Treatment of lymphoblastic lymphoma in adults. Best Pract Res Clin Haematol 2002;15(4):713-728

12 Hollender A, Kvaloy S, Nome O, Skovlund E, Lote K, Holte H. Central nervous system involvement following diagnosis of non-Hodgkin's lymphoma: a risk model. Ann Oncol 2002;13(7):1099-1107

13 Feugier P, Virion JM, Tilly $\mathrm{H}$, et al. Incidence and risk factors for central nervous system occurrence in elderly patients with diffuse large-B-cell lymphoma: influence of rituximab. Ann Oncol 2004;15(1):129-133

14 Badr MA, Hassan TH, El-Gerby KM, Lamey ME. Magnetic resonance imaging of the brain in survivors of childhood acute lymphoblastic leukemia. Oncol Lett 2013;5(2):621-626

15 Mahmoud HH, Rivera GK, Hancock ML, et al. Low leukocyte counts with blast cells in cerebrospinal fluid of children with newly diagnosed acute lymphoblastic leukemia. N Engl J Med 1993;329(5):314-319

16 Smith M, Arthur D, Camitta B, et al. Uniform approach to risk classification and treatment assignment for children with acute lymphoblastic leukemia. J Clin Oncol 1996;14(1):18-24

17 Pui CH, Campana D, Pei D, et al. Treating childhood acute lymphoblastic leukemia without cranial irradiation. N Engl J Med 2009;360(26):2730-2741

18 Pui CH, Evans WE. Treatment of acute lymphoblastic leukemia. N Engl J Med 2006;354(2):166-178

19 Dennis AC, Acute leukemia and myelodysplastic syndromes. In: Mary CT, ed. Lippincott Manual of Oncology. Philadelphia, PA: Wolters Kluwer; 2008840 